\title{
Suplementasi Ekstrak Bilberry Menurunkan Kadar Malondialdehid Lensa Penderita Katarak Senilis
}

\section{Bilberry Extract Supplementation Decrease Malondialdehyde Levels in Senile Cataract Lens Patient}

\author{
T Budi Sulistya, Alfi Mutammima \\ Laboratorium Ilmu Kesehatan Mata Rumah Sakit Umum Dr. Saiful Anwar Malang
}

\begin{abstract}
ABSTRAK
Salah satu faktor yang berperan pada katarak senilis adalah stres oksidatif. Penelitian ini bertujuan untuk mengevaluasi pengaruh ekstrak bilberry untuk mengurangi kadar malondialdehid lensa katarak senilis. Uji klinis tersamar ganda dilakukan dengan 33 orang pasien katarak senilis. Subjek dibagi menjadi 3 kelompok secara merata yaitu plasebo, perlakuan 100 mg ekstrak bilberry dan 300 mg ekstrak bilberry. Pengobatan yang diberikan sampai 14 hari sebelum operasi katarak untuk mengevaluasi tingkat malondialdehid. Data dianalisis menggunakan ANOVA dan uji Tukey. Tingkat

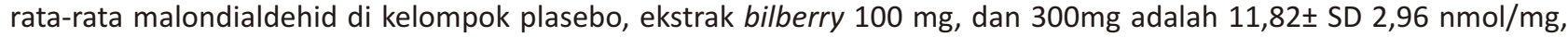
$7,99 \pm S D 1,99 \mathrm{nmol} / \mathrm{mg}$, dan 5,22 1 1,27SD nmol$/ \mathrm{mg}$. Efek penurunan malondialdehid dengan pemberian $100 \mathrm{mg}$ dan 300 mg ekstrak bilberry berbeda signifikan $(p<0,05)$. Terdapat korelasi negatif antara ekstrak bilberry dan malondialdehid tergantung dosis $(r=-0,760 ; p<0,001)$. Diagram menunjukkan bahwa peningkatan dosis ekstrak bilberry akan mengakibatkan penurunan tingkat malondialdehid pada pasien katarak senilis. Dapat disimpulkan bahwa pemberian ekstrak suplemen bilberry dapat mengurangi kadar malondialdehid di lensa pasien katarak senilis dan peningkatan dosis ekstrak bilberry berkorelasi dengan tingkat penurunan malondialdehid pada lensa penderita katarak senilis.
\end{abstract}

Kata Kunci: Ekstrak bilberry, katarak senilis, malondialdehid

\begin{abstract}
Oxidative stress plays an important role in the pathogenesis of senile cataract. The study aimed to evaluate the effect of bilberry extract to reduce the levels of malondialdehyde of senile cataract lens. A double randomized clinical study was performed using 33 senile cataract subjects. The subjects were divided into 3 equal groups which are placebo, treatment with $100 \mathrm{mg}$ bilberry extract and $300 \mathrm{mg}$ bilberry extract. Treatment was provided start from 14 days prior to cataract surgery to evaluate malondialdehyde level. Data was analyzed using ANOVA and Tukey test. The average level of

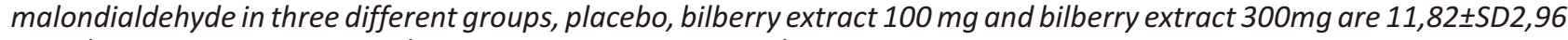

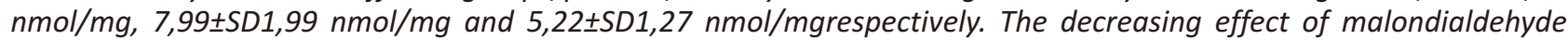
between group bilberry extract $100 \mathrm{mg}$ and bilberry extract $300 \mathrm{mg}$ were significantly different $(p<0,05)$. There is a negative correlation between bilberry extract dose and level of malondialdehyde $(r=-0,760 ; p<0,001)$. The higher the extract bilberry dose the lower the malondialdehyde level in senile cataract lens $(r=-0,760, p=0,000)$. It can be concluded that extract bilberry supplementation can reduce the levels of malondialdehyde in lens of senile cataract patients.
\end{abstract}

Keywords: Bilberry extract, malondialdehide, senile cataract

Jurnal Kedokteran Brawijaya, Vol. 26, No. 4, Agustus 2011; Korespondensi: Alfi Mutammima. Laboratorium IImu Kesehatan Mata Rumah Sakit Umum Dr. Saiful Anwar Malang, Jl. Jaksa Agung Suprapto No.2 Malang, Tel. (0341) 341945 Email: alfi_mutammima@yahoo.com 


\section{PENDAHULUAN}

Katarak merupakan penyebab kebutaan nomor satu di seluruh dunia (1), dengan jenis katarak terbanyak adalah katarak senilis (katarak terkait usia) (2). Katarak senilis adalah suatu penyakit degenerasi, yaitu lensa mata yang seharusnya jernih berubah menjadi keruh. Organisasi Kesehatan Dunia (WHO) memperkirakan sekitar 17 juta orang di dunia mengalami kebutaan akibat katarak pada tahun 2010 dan akan meningkat mencapai 40 juta pada tahun 2020 (3).

Penatalaksanaan utama katarak sampai saat ini masih dengan cara pembedahan yakni ekstraksi katarak. Masih terdapat kesulitan yang dihadapi sampai saat ini terkait dengan penatalaksanaan katarak, antara lain pelayanan yang belum merata, tingginya angka buta katarak, tenaga pemberi pelayanan yang masih terbatas, dan mahalnya biaya menyebabkan penumpukan penderita (backlog) (4). Di seluruh dunia diperkirakan terdapat backlog sekitar 10 juta penderita setiap tahun (5). Di Indonesia berdasarkan hasil Survey Kesehatan Indera tahun 19931996, sebesar 1,5\% penduduk Indonesia mengalami kebutaan dengan penyebab utama katarak (0,78\%), glaukoma $(0,20 \%)$, kelainan refraksi $(0,14 \%)$, gangguan retina $(0,13 \%)$, dan kelainan kornea $(0,10 \%)$. Insiden kebutaan katarak di Indonesia diperkirakan 1 orang permil (210.000/tahun), sedangkan penderita yang dapat dioperasi baru sekitar 80.000 orang pertahun (6). Akibatnya timbul backlog katarak yang cukup tinggi (sekitar 1.720 .000 penderita) pertahun $(4,6)$. Jika terjadinya katarak dapat ditunda sampai 10 tahun maka akan menurunkan kebutuhan operasi katarak sampai 45$50 \%(7,8)$

Patogenesa terjadinya katarak senilis sampai saat ini belum diketahui dengan pasti dan multifaktorial (3), namun diketahui salah satu faktor penting yang berperan dalam pembentukan katarak senilis adalah stres oksidatif (3,8-10). Salah satu faktor resiko penyebab timbulnya stres oksidatif adalah adanya paparan cahaya matahari/ultraviolet berlebihan. Paparan ini akan membentuk spesies oksigen yang sangat reaktif yang akan menyebabkan deaktivasi sistem enzim sulfhydryldependent, agregasi protein dengan membentuk jembatan disulfid, kerusakan struktur membran sel karena proses peroksidasi lemak dan kerusakan asam deoksiribonukleat (ADN). Efek fotokimia ini pada akhirnya menyebabkan kekeruhan lensa yang menetap (3-10). Salah satu indikator terjadinya stres oksidatif dengan dihasilkan salah satu produk akibat adanya kerusakan jaringan. Salah satunya adalah kadar malondialdehid yang meningkat (10-13). Dalam keadaan normal lensa memiliki mekanisme pertahanan terhadap stres oksidatif dan radikal bebas yang terbentuk yakni antioksidan (13). Mekanisme ini ada yang bersifat enzimatik seperti glutation peroksidase (GPx), glutation reduktase (GR), superoksid dismutase (SOD), dan non enzimatik seperti vitamin C (askorbat) dan E ( $\alpha$-tokoferol), dan $\beta$ karoten (3, 9,10,14,15).

Beberapa penelitian berkembang untuk melihat peran suplemen antioksidan terhadap terjadinya stres oksidatif antara lain Wahyu dan Gondhowiardjo memperlihatkan pemberian kombinasi suplementasi vitamin $\mathrm{E}$ dan $\mathrm{C}$ selama 2 minggu mempunyai efek yang sinergis menurunkan tingkat stres oksidatif di humor akuos dan lensa katarak dibandingkan pemberian vitamin $\mathrm{E}$ atau $\mathrm{C}$ saja (16). Penelitian Seth $R K$ et al pada 50 penderita katarak yang diberikan vitamin E 100 mg, dua kali sehari selama 30 hari dibandingkan plasebo memperlihatkan vitamin $\mathrm{E}$ menurunkan kadar stres oksidatif dengan menurunnya nilai malondialdehid (17).

Vaccinium myrtillus (billberry) sejak lama digunakan untuk mengatasi gangguan mata. Komponen aktifnya flavonoid anthosianid merupakan antioksidan poten dengan pengaruh kuat pada mata dan vaskuler. Dilaporkan suatu penelitian dengan desain tersamar ganda, yang menggunakan kontrol plasebo dilakukan pemberian kombinasi ekstrak bilberry $180 \mathrm{mg}$ dan vitamin E $100 \mathrm{mg}$ dua kali sehari selama 4 bulan pada 50 penderita katarak senilis akan menghambat progresifitas katarak pada $96 \%$ subjek yang diberikan terapi dibandingkan $76 \%$ pada grup kontrol (10).

Penelitian Thohir dkk menyebutkan bahwa suplementasi ekstrak bilberry pada tikus yang dipapar radiasi sinar gamma (cobalt 60) menyebabkan penurunan kadar malondialdehid lensa tikus secara signifikan, dan kadar malondialdehid lensa tikus yang dipapar radiasi tersebut semakin menurun bermakna dengan bertambah tingginya dosis ekstrak bilberry yang diberikan (18).

Pada penelitian ini dikaji efek pemberian ekstrak bilberry dosis $100 \mathrm{mg}$ dan $300 \mathrm{mg}$ terhadap penurunan kadar malondialdehid lensa mata penderita katarak senilis. Pengaruh ekstrak bilberry sebagai antioksidan diharapkan memberikan pengaruh pada penurunan kadar malondialdehid sebagai salah satu indikator proses degradasi asam lemak tak jenuh pada lensa katarak. Hasil penelitian ini diharapkan dapat mengetahui efek pemberian ekstrak bilberry terhadap penurunan kadar malondialdehid lensa katarak senilis dan mengetahui peranan ekstrak bilberry dalam menunda onset terjadinya katarak senilis dilihat dari aspek stres oksidatif

\section{METODE}

Penelitian ini merupakan double blind randomized clinical study. Penelitian ini dilakukan di Poliklinik Sub bagian Kornea dan Lensa, Kamar Operasi Bagian Ilmu Kesehatan Mata Rumah Sakit Umum Dr. Saiful Anwar Malang dan Laboratorium Faal Fakultas Kedokteran Universitas Brawijaya Malang. Populasi terjangkau dari penelitian ini adalah penderita katarak senilis yang berobat ke Poliklinik Subbagian Kornea dan Lensa, Bagian Ilmu Kesehatan Mata Rumah Sakit Umum Dr. Saiful Anwar Malang.

Kriteria inklusi pada penelitian ini adalah penderita katarak senilis sesuai kriteria Buratto I-V pada satu atau dua mata yang akan menjalani ekstraksi katarak, tidak memiliki kebiasaan merokok minimal dalam tiga bulan terakhir, tidak menderita diabetes mellitus, tidak menggunakan suplementasi multivitamin atau antioksidan dalam satu bulan terakhir dan telah mendapatkan penjelasan mengenai pemeriksaan dan tindakan yang akan dilakukan serta bersedia menandatangani persetujuan resmi. Kriteria eksklusi yang digunakan adalah penderita yang tidak meminum obat sesuai aturan yang ditentukan, penderita tidak datang pada jadwal yang ditentukan, keadaan yang menyebabkan penderita tidak dapat dilakukan ekstraksi katarak sesuai jadwal yang ditentukan, misalnya menderita infeksi mata dan gangguan teknis perbaikan kamar operasi. Seluruh 
penderita yang masuk dalam penelitian ini sebanyak 36 orang. Jumlah penderita yang tereksklusi dari penelitian ini sebanyak 3 orang penderita, dengan alasan 2 orang penderita mengalami penundaan jadwal operasi karena ada perbaikan kamar operasi dan 1 orang penderita lupa untuk meminum obat sesuai jadwal yang ditentukan, sehingga didapatkan 33 sampel. Sampel penelitian dikelompokkan menjadi 3 yaitu kelompok yang mendapatkan plasebo, suplementasi ekstrak bilberry 100 $\mathrm{mg} /$ hari dan suplementasi ekstrak bilberry $300 \mathrm{mg} /$ hari.

Penderita yang memenuhi kriteria inklusi diminta memilih obat secara acak yakni, botol berisi kapsul dengan 3 warna yakni merah-putih, abu-hitam dan kuning-hijau. Baik penderita maupun peneliti tidak mengetahui isi dari kapsul apakah plasebo atau ekstrak bilberry. Warna kapsul yang dipilih penderita akan dicatat. Kandungan kapsul diketahui saat data akan dianalisa (setelah semua data didapatkan). Setelah semua data didapatkan, kandungan kapsul baru diketahui yakni kapsul merah-putih berisi ekstrak bilberry 100mg, hijau-kuning berisi ekstrak bilberry $300 \mathrm{mg}$ dan abu-hitam berisi plasebo.

Pemberian suplementasi dilakukan selama 14 hari sebelum menjalani ekstraksi katarak karena pada lensa yang dikultur terlihat parameter biological sel lensa masih normal termasuk kejernihan lensa sampai 14 hari. Oleh karena itu periode perlakuan stres oksidatif dilakukan dalam kurun waktu tersebut (19). Setelah itu dilakukan ekstraksi katarak dan pada saat itu dilakukan pengambilan nukleus lensa pada masing-masing subyek penelitian, kemudian dilakukan pemeriksaan kadar malondialdehid lensa dengan alat spektrofotometer. Untuk mengetahui perbedaan rata-rata kadar malondialdehid pada setiap dosis pengamatan dilakukan analisis One Way ANOVA, dilanjutkan dengan uji perbandingan ganda (multiple comparison, Tukey). Data disajikan dalam bentuk tabulasi dengan program SPSS 15.0 for window. Untuk mengetahui pengaruh ekstrak bilberry terhadap penurunan kadar malondialdehid dilakukan dengan uji korelasi dan regresi. Kemaknaan ditentukan berdasarkan nilai $p<0,05$

\section{HASIL}

Karakteristik demografi yang dievaluasi pada penelitian ini meliputi usia pasien dan jenis kelamin, dan gradasi katarak. Hasil uji beda menunjukkan bahwa tidak ada perbedaan yang bermakna antara ketiga kelompok penelitian dalam karakteristik demograsi, sehingga ketiga kelompok dapat dianggap berasal dari populasi homogen (Tabel 1).

Tabel 1. Karakteristik sampel pada ketiga kelompok

\begin{tabular}{|c|c|c|c|c|c|c|c|}
\hline Karakteristik demografi & \multicolumn{2}{|r|}{$\begin{array}{c}\text { Kontrol } \\
(n=9)\end{array}$} & \multicolumn{2}{|c|}{$\begin{array}{c}\text { Kelompok } \\
\text { dengan Bilberry } \\
100 \mathrm{mg}(\mathrm{n}=9)\end{array}$} & \multicolumn{2}{|c|}{$\begin{array}{c}\text { Kelompok } \\
\text { dengan Bilberry } \\
300 \mathrm{mg}(\mathrm{n}=9)\end{array}$} & \multirow{2}{*}{$\begin{array}{c}\text { p-value } \\
0,901^{*}\end{array}$} \\
\hline 1. Usia (mean $\pm S D)$ & 59,7 & $2 \pm S D$ 9,09 & 60,9 & \pm SD 6,41 & 59.55 & \pm SD 6.96 & \\
\hline 2. Jenis kelamin & & & & & & & $0,319^{*}$ \\
\hline Laki -laki & 5 & $45,5 \%$ & 2 & $18,2 \%$ & 5 & $45,5 \%$ & \\
\hline Perempuan & 6 & $54,5 \%$ & 9 & $81,8 \%$ & 6 & $54,5 \%$ & \\
\hline Gradasi Katarak & & & & & & & $0,759^{*}$ \\
\hline Grade 3 & 1 & $9,1 \%$ & 1 & $9,1 \%$ & 2 & $18,2 \%$ & \\
\hline Grade 4 & 10 & $90,9 \%$ & 10 & $90,9 \%$ & 9 & $81,8 \%$ & \\
\hline
\end{tabular}

Rata-rata kadar malondialdehid tiap kelompok perlakuan memperlihatkan hasil yang bervariasi. Pada kelompok kontrol didapatkan rata-rata malondialdehid adalah $11,82 \pm S D 2,96 \mathrm{nmol} / \mathrm{mg}$, pada kelompok ekstrak bilberry $100 \mathrm{mg} 7,99 \pm$ SD1,99 $\mathrm{nmol} / \mathrm{mg}$, dan kelompok ekstrak

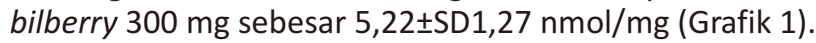
Grafik menunjukkan bahwa kadar malondialdehid pada pemberian ekstrak bilberry $100 \mathrm{mg}$ lebih rendah dibandingkan kontrol, demikian juga pada pemberian eksrak bilberi $300 \mathrm{mg}$.

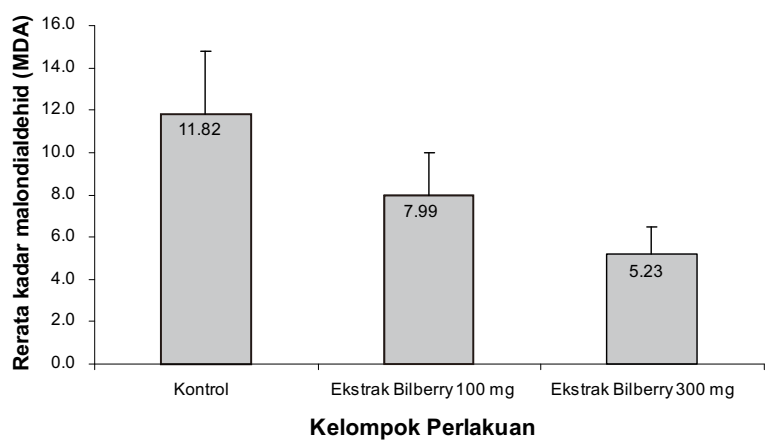

Grafik1. Rerata kadar malondialdehid dalam beberapa kelompok perlakuan

Uji pembandingan berganda antara pada setiap perlakuan pada Tabel 2, menunjukkan bahwa terdapat perbedaan signifikan kadar malondialdehid antar masing-masing kelompok. Kadar malondialdehid pada pemberian ekstrak bilberry $100 \mathrm{mg}$ lebih rendah bermakna dibandingkan kontrol $(p=0,001)$. Pemberian dosis $300 \mathrm{mg}$ menunjukkan kadar malondialdehid yang secara signifikan lebih rendah dibandingkan pemberian dosis $100 \mathrm{mg}(p=0,016)$ dan kontrol $(p<0,001)$.

Tabel 2. Hasil uji Tukey kadar malondialdehid lensa penderita katarak senilis pada setiap kelompok perlakuan

\begin{tabular}{cccc}
\hline \multirow{2}{*}{ Perbandingan } & perlakuan & Beda rata-rata & p-value \\
& & 3,829 & 0,001 \\
\multirow{2}{*}{ Kontrol } & Dosis $100 \mathrm{mg}$ & 6,592 & 0,000 \\
& Dosis $300 \mathrm{mg}$ & 2,762 & 0,016 \\
\hline
\end{tabular}

Peningkatan dosis ekstrak bilberry cenderung akan menurunkan kadar malondialdehid lensa penderita katarak senilis, dibandingkan dengan kadar malondialdehid pada dosis yang lebih rendah $(r=-0,760 ; p=0,000)$. Uji regresi menghasilkan model persamaan $y=11,118-0,021 x$. Hal ini dapat diartikan bahwa tanpa dipengaruhi oleh faktor pemberian ekstrak bilberry, maka kadar malondialdehid lensa penderita katarak senilis akan cenderung tetap meningkat secara konstan $11,118 \mathrm{nmol} / \mathrm{mg}$, setiap peningkatan dosis ekstrak bilberry $1 \mathrm{mg}$ akan menyebabkan kadar malondialdehid mengalami penurunan hingga 0,021 $\mathrm{nmol} / \mathrm{mg}$. Pemberian dosis ekstrak bilberry mempengaruhi keragaman kadar malondialdehid lensa penderita katarak senilis hingga $57,8 \%$. 


\section{DISKUSI}

Penggunaan antioksidan dipercaya dapat menunda, menghambat, atau mengurangi proses stres oksidasi yang terjadi. Ekstrak bilberry dipercaya sejak lama sebagai antioksidan poten terkait dengan susunan aglikonnya, yakni grup hidroksil bebas di sekeliling cincinnya yang terdiri dari atom hidrogen. Molekul ini dapat berpasangan dengan radikal bebas untuk menetralkan elektron bebas milik radikal bebas (18).

Pada analisis One Way ANOVA untuk mengetahui perbedaan pengaruh dari variasi dosis ekstrak bilberry terhadap kadar malondialdehid lensa katarak senilis pada setiap kelompok perlakuan, didapatkan hubungan yang signifikan $p<0,05$, sehingga dapat dikatakan terdapat perbedaan kadar malondialdehid lensa penderita katarak senilis pada setiap kelompok perlakuan ekstrak bilberry. Yao $\mathrm{N}$ et al yang meneliti pemberian ekstrak bilberry $42 \%$ anthosianin pada tikus yang telah diinduksi endotoksin lipopolisakarida, yang diberikan ekstrak bilberry pada dosis 50,100, $200 \mathrm{mg} / \mathrm{kg} /$ hari selama 5 hari. Terlihat bahwa efek pemberian ekstrak bilberry dapat menurunkan kadar molondialdehid dan meningkatkan enzim prooksidan seperti glutation, glutation peroksidase dan vitamin C. Hal ini memperlihatkan bahwa ekstrak bilberry dapat mengatasi stres oksidatif (20).

Pada pengujian berganda dengan uji Tukey didapatkan perbedaan yang signifikan antara setiap kelompok kontrol dan perlakuan yakni ekstrak bilberry 100 mg dan ekstrak bilberry $300 \mathrm{mg}$. Pemberian ekstrak bilberry $300 \mathrm{mg}$ dapat menurunkan kadar malondialdehid lebih rendah dibandingkan ekstrak bilberry $100 \mathrm{mg}$. Hal ini sesuai dengan penelitian Thohir dkk, meneliti pemberian ekstrak bilberry pada tikus Ratus novergicus strain wistar pada dosis $50 \mathrm{mg} / \mathrm{kg}, 150 \mathrm{mg} / \mathrm{kg}$, dan $450 \mathrm{mg} / \mathrm{kg}$ yang dipapar radiasi kranium total dosis tunggal 5Gy. Hasil menunjukkan hambatan kadar malondialdehid paling rendah pada dosis ekstrak bilberry tertinggi yaitu

\section{DAFTAR PUSTAKA}

1. El-Ghaffar A, Aziz MA, Mahmoud AM, and Al Balkini SM. Elevation of Plasma Nitrate and Malondialdehyde in Patients with Aged Related Cataract. Middle East African Journal of Ophthalmology. 2007; 14(1): 13-15.

2. Mirsamadi M, Nourmohammadi I, and Imamian M. Comparative Study of Serum $\mathrm{Na}+$ and $\mathrm{K}+$ levels in Senile Cataract Patients and Normal Individual. International Journal of Medical Sciences. 2004; 1: 165-169.

3. American Academy of Opthalmology Staff. Lens and Cataract. Basic and Clinical Course. Section 11. San Francisco: American Academy of Opthalmology; 2008-2009: p. 16-17,71-74

4. Menteri Kesehatan Repubik Indonesia. Rencana Strategi Nasional Penanggulangan Gangguan Penglihatan dan Kebutaan untuk Mencapai Vision 2020. [Keputusan Menteri]. Jakarta. 2005.

5. Taylor HR. Cataract: How Much Surgery do We Have To Do? . British Journal of Opthalmology. 2000; 84: 1-2

6. Pramono. Setiap Menit Satu Anak menjadi Buta. 450mg/kg (18).

Penelitian ini membuktikan bahwa semakin besar peningkatan dosis ekstrak bilberry akan cenderung menurunkan kadar malondialdehid. Walaupun dosis 100 mg ini telah berhasil menurunkan kadar malondialdehid lensa katarak secara signifikan, namun dosis ekstrak bilberry $300 \mathrm{mg}$ memberikan efek penurunan stres oksidatif lensa katarak senilis yang lebih baik dibandingkan ekstrak bilberry $100 \mathrm{mg}$, terlihat dengan kadar malondialdehid yang lebih rendah.Pemberian ekstrak bilberry mempengaruhi keragaman kadar malondialdehid lensa sebanyak $57,8 \%$ dan sisanya dipengaruhi faktor lain. Beberapa faktor yang dapat mempengaruhi pengukuran kadar malondialdehid yang mencerminkan tingkat stres oksidatif jaringan, antara lain penyakit diabetes mellitus, konsumsi rokok, dan konsumsi antioksidan, sehingga faktor ini disingkirkan pada penelitian ini. Faktor lain seperti paparan sinar matahari dan diet intake tiap pasien yang berbeda, sulit untuk dikontrol pada tiap pasien (9).

Dosis ekstrak bilberry yang digunakan pada penelitian ini sebesar $100 \mathrm{mg}$ dan $300 \mathrm{mg}$. Lee J et al melaporkan dalam penelitiannya dengan 60 subjek penderita myopia antara $1,00 \mathrm{D}$ sampai $-8,00 \mathrm{D}$ yang mempunyai gejala penyerta asthenopia, diberikan ekstrak bilberry $100 \mathrm{mg}$ selama 4 minggu, hasilnya memperbaiki gejala subjektif dan objektif penderita yakni gangguan asthenopia dan peningkatan kontras sensitivitas dalam kondisi gelap (21). Pertimbangan pemberian dosis ekstrak bilberry $300 \mathrm{mg}$ untuk mengetahui kadar malondialdehid pada pemberian ekstrak bilberry dengan dosis yang lebih tinggi (3 kali lipat dosis awal). Pada penelitian in vitro membuktikan pemberian ekstrak bilberry pada dosis yang lebih tinggi memberikan penurunan kadar stres oksidatif yang terlihat dengan penurunan kadar malondialdehid (22). Dapat disimpulkan dari hasil penelitian ini bahwa pemberian ekstrak bilberry pada dosis $100 \mathrm{mg}$ dan $300 \mathrm{mg}$ dapat menurunkan kadar malondialdehid pada lensa katarak senilis.

(Online) 2007. http://www.tempointeractive.com /hg/nasional/2007/10/12/brk,20071012-109482 ,id.html

7. National Eye Institute. Cataract. (Online) 2009. http://www.nei.nih.gov/health/cataract/cataract_fac ts.asp.

8. Pelman JAM, Lely BJ, Klein R, et al. Vitamin Supplement Use and Incident Cataracts in a Population Based Study. Archives of Ophthalmology. 2000; 118(11): 1556-1563.

9. Ates NA, Yildirim O, Tamer L, et al. Plasma Catalase Activity and Malondialdehyde Level in Patients with Cataract. Eye. 2004; 18: 785-788.

10. Head K. Natural Therapies for Ocular Disorders. Part Two: Cataract and Glaucoma. Alternative Medical Review. 2001; 6(2): 142-145.

11. Palmieri B and Sblendorio V. Oxidative Stress Tests: Overview on Reliability and Use. Part 1. European Review for Medical and Pharmacological Sciences. 2007; 11(5): 309-342.

12. Varma SD. Scientific Basis for Medical Therapy of Cataracts by Antioxidants. American Journal Society 
for Clinical Nutrition. 1991; 53: 335-345.

13. Saygili El, Aksoy SN, Gurler B, Akson A, Erel O, and Ozaslan M. Oxidant/Antioxidant Status of Patient with Diabetic and Senile Cataract. Biotechnology \& Biotechnological Equipment. 2010; 24(1): 1648-1652.

14. Brown, NP. Mechanism of Cataract Formation. Journal of Optometri. 2001;3(4): 21-31.

15. Droge W. Free Radical with the Physiological Control of All Function. Physiological Reviews. 2008; 82(1): 4795.

16. Wahyu L dan Gondowiardjo TD. Efek Suplementasi Vitamin C dan E terhadap Stres Oksidatif pada Lensa Katarak. Majalah Opthalmology Indonesia. 2004; 31(3): 194-200.

17. Seth RK and Kharb S. Protective Function of Alphatocopherol Against the Process of Cataractogenesis in Human. Annals of Nutrition and Metabolism. 1999; 435: 286-289.

18. Thohir A, Sulistya TB, dan Santoso SA. Efek Suplementasi Ekstrak Bilberry terhadap Kadar
Malondialdehid Lensa Tikus yang Dipapar Radiasi Cranium Total. [Thesis]. Univesitas Brawijaya Malang, Malang. 2008.

19. Spector A. Oxidative Stress-Induced Cataract: Mechanism of Action. The Federation of American Societies for Experimental Biology Journal. 1995; 9: 1173-1180

20. Yao N, Fan L, He RR, and Kurihara H. Protective Effect of Bilberry (Vaccinium Myrtilus) Extract Againts Endotoxin Induce Uveitis in Mice. Journal of Agricultural and Food Chemistry. 2010; 58(8): 47314736.

21. Lee J, Lee HK, Kim CY, et al. Purified High-dose Anthocyanoside Oligomer Administration Improves Nocturnal Vision and Clinical Symptoms in Myopia Subjects Institute of Vision Research. British Journal of Nutrition. 2007; 93: 895-899.

22. Antal DS, Garban G, and Garban Z. The Anthocyans: Biologically-Active Substance of Food and Pharmaceutic Interest. The Annals of the University Dunarea de Jos of Galati. 2003; 6(106): 106-116. 